\title{
Spectrophotometrical Study of the Physisorption of Iron(II) Clathrochelates Containing Terminal Phenanthrenyl Group(s) on Carbon Paper
}

\author{
Yan Z. Voloshin, ${ }^{\mathrm{a}, \mathrm{b} @ ~ N i n a ~ V . ~ C h o r n e n k a, ~}{ }^{\mathrm{c}}$ Alexander S. Belov, ${ }^{\mathrm{d}}{ }$ Sergey A. Grigoriev, ${ }^{\mathrm{e}}$ \\ Artem S. Pushkarev, ${ }^{\text {e,f }}$ Pierre Millet, ${ }^{g}$ Valery N. Kalinichenko, ${ }^{\text {h }}$ Irina G. Belaya, ${ }^{\text {a,d }}$ \\ Margarita G. Bugaenko, ${ }^{a, d}$ and Alexey G. Dedov a,b
}

\begin{abstract}
${ }^{\mathrm{a}}$ Gubkin Russian State University of Oil and Gas (National Research University), 119991 Moscow, Russia
${ }^{\mathrm{b}}$ Kurnakov Institute of General and Inorganic Chemistry of the Russian Academy of Sciences, 119991 Moscow, Russia

${ }^{\mathrm{c}}$ Vernadskii Institute of General and Inorganic Chemistry NASU, 03142 Kyiv, Ukraine

${ }^{\mathrm{d} N e s m e y a n o v}$ Institute of Organoelement Compounds of the Russian Academy of Sciences, 119991 Moscow, Russia

'National Research University "Moscow Power Engineering Institute”, 111250 Moscow, Russia

${ }^{\mathrm{f}}$ National Research Centre "Kurchatov Institute", 123182 Moscow, Russia

'Institut de Chimie Moléculaire et des Matériaux d'Orsay, Université Paris-Sud, 91405 Orsay, France

${ }^{\mathrm{h}}$ Semenov Institute of Chemical Physics, 119991 Moscow, Russia

@Corresponding authorE-mail:voloshin@ineos.ac.ru
\end{abstract}

\begin{abstract}
Transition metal clathrochelates form a family of the compounds of great practical interest for the hydrogen evolution reaction in acidic electrolytes. When adequately immobilized on the surface of appropriate carbonaceous substrates, they can find application at the cathode of polymer electrolyte membrane water electrolysis cells. The physisorption of the mono-, di- and hexa-functionalized phenanthrenyl-terminated iron(II) clathrochelates, which were especially designed for their effective immobilization onto carbonaceous substrates, onto a carbon paper of practical interest, was studied by UV-Vis spectrophotometry. It was found that the larger the number of polyaromatic groups per a clathrochelate molecule, the stronger the physisorption is. Despite a larger steric hindrance, the complexes with several polyaromatric groups are prone to stronger physisorption on carbonaceous substrates. The physisorption of Methylene Blue dye, a model compound, was used as reference for comparison.
\end{abstract}

Keywords: Macrocyclic compounds, clathrochelates, iron complexes, physical adsorption, carbonaceous materials.

\section{Спектрофотометрическое изучение физической аАсорбции клатрохелатов железа(II) с терминальными(-ой) фенантренильными(-ой) группами(-ой) на углеродной бумаге}

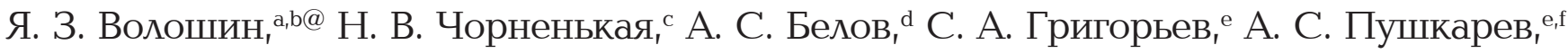 \\ П. Мийе, ${ }^{\mathrm{g}}$ В. Н. Калиниченко, ${ }^{\mathrm{h}}$ И. Г. Белая, ${ }^{\mathrm{a}, \mathrm{d}}$ М. Г. Бугаенко, ${ }^{\mathrm{a}, \mathrm{d}}$ А. Г. Аедавов

\footnotetext{
ароссийский государственный университет нефти и газа им. И.М. Губкина (Нацииональный исследовательский университет), 119991 Москва, Россия

' Институт общей и неорганической химии им. Н.С. Курнакова РАН, 119991 Москва, Россия

'Институт общей и неорганической химии им. В.И. Вернадского НАН Украины, 03142 Киев, Украина

${ }^{\mathrm{d}}$ Институт элементоорганических соединений им. А.Н. Несмеянова РАН, 119991 Москва, Россия

'Национальный исследовательский университет «МЭИ», 111250 Москва, Россия

${ }^{\mathrm{f}}$ Национальный исследовательский иентр «Курчатовский институт», 123182 Москва, Россия

${ }^{\mathrm{g}}$ Институт молекулярной химии и материалов Орсэй, Университет Пари-Сюд, 91405 Орсэй, Франция

'Институт химической физики им. Н.Н. Семёнова РАН, 119991 Москва, Россия

${ }^{\circledR}$ E-mail:voloshin@ineos.ac.ru
} 
Клатрохелаты переходных металлов являются представителями класса соединений, представляюших большой практический интерес с точки зрения реакции получения водорода в водных электролизерах. В случае их иммобилизации на подходящую поверхность углеродного материала, эти комплексы могут быть использованы при изготовлении катодов полимерной электролитной мембраны в ячейках для электролиза воды. Физическая адсорбциия моно-, ди- и гексафункиионализированных клатрохелатов железа(II) с терминальныли фенантренильными группами(-ой), дизайн молекул которых был направлен на их эффективную иммобилизаизию на углеродные носители, на практически используемую углеродную бумагу, была изучена методами спектрофотометрии в видимой и УФ-областях. Установлено, что увеличение числа полиароматических групп приводит к увеличению физической адсорбции: несмотря на значительные стерические затруднения, комплексы с несколькими такими терминальными функиионализирующими группами продемонстрировали более сильную адсорбцию на углеродных носителях. Для сравнения была также изучена физическая адсорбиия красителя Метиленового голубого как модельного соединения на вышеупомянутых носителях.

Ключевые слова: Макроциклические соединения, клатрохелаты, комплексы железа, физическая адсорбция, углеродные материалы.

\section{Introduction}

Transition metal clathrochelates ${ }^{[1]}$ form a large family of coordination compounds of great practical interest for the hydrogen evolution reaction (HER) in acidic electrolytes. When adequately immobilized on the surface of appropriate carbonaceous substrates, they can find application at the cathode of polymer electrolyte membrane (PEM) water electrolysis cells, a cornerstone technology in the frame of the energy transition and the hydrogen economy. ${ }^{[2]}$ Several earlier reports ${ }^{[3,4]}$ have demonstrated the interest of these complexes to replace platinum for the HER in PEM cells, but their practical application requires further optimization. Our ultimate goal is to form homogenous and monolayer
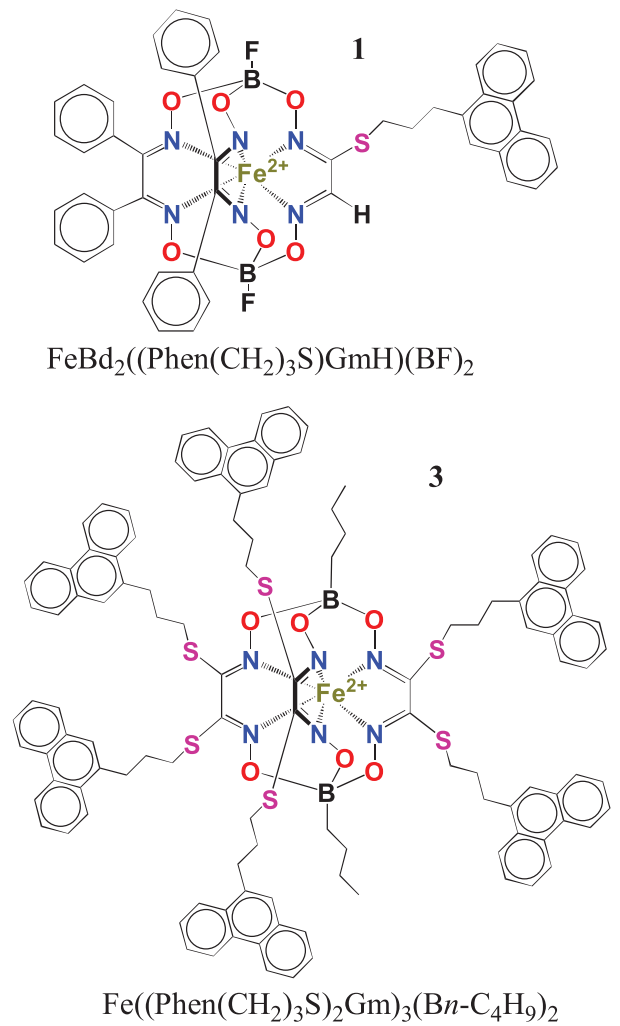

thick coatings onto the carbon fibers of gas-diffusion layers. This can be achieved by either self-assembly (physisorption) or electrografting. In this communication, we report on the physisorption of three polyaromatic-terminated iron(II) cage complexes (clathrochelates), ${ }^{[5]}$ specifically designed ${ }^{[6]}$ for their effective adsorption on carbonaceous substrates, onto a carbon paper (CP) made of carbon fibers. This CP is used as a gas-diffusion layer (GDL) in fuel cell technology. Considering the fact that there are strong physical interactions between aromatic groups and carbonaceous substrates, three different complexes containing one, two and six terminal (poly)aromatic group(s), respectively (Scheme 1), have been synthesized and used in the experiments. Our objective was to collect sorption data to better understand

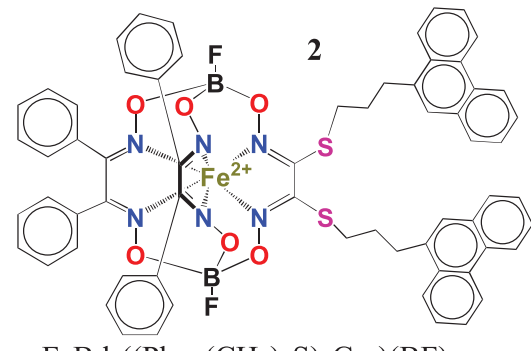

$\mathrm{FeBd}_{2}\left(\left(\mathrm{Phen}\left(\mathrm{CH}_{2}\right)_{3} \mathrm{~S}\right)_{2} \mathrm{Gm}\right)(\mathrm{BF})_{2}$

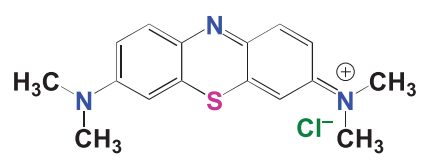

Methylene Blue

Scheme 1. Chemical drawings of the compounds under study. 
the influence of stereochemistry on compound-surface interactions. Several results have been reported in a previous publication. ${ }^{[7]}$ Carbon paper with its very large surface area is known as a material of practical interest in the electrochemical industry. It can be used as gas-diffusion-layer (GDL) in PEM fuel cell technology and as cathode current collector in PEM water electrolysis technology. ${ }^{[8]}$

\section{Experimental}

\section{Materials}

Three different complexes of interest, namely $\mathrm{FeBd}_{2}\left(\left(\mathrm{Phen}\left(\mathrm{CH}_{2}\right)_{3} \mathrm{~S}\right) \mathrm{GmH}\right)(\mathrm{BF})_{2}, \mathrm{FeBd}_{2}\left(\left(\mathrm{Phen}\left(\mathrm{CH}_{2}\right)_{3} \mathrm{~S}\right)_{2} \mathrm{Gm}\right)(\mathrm{BF})_{2}$ (where $\mathrm{Bd}^{2-}$ stands for $\alpha$-benzildioxime dianion and $\mathrm{Gm}$ stands for glyoxime residue $)$ and $\mathrm{Fe}\left(\left(\mathrm{Phen}\left(\mathrm{CH}_{2}\right)_{3} \mathrm{~S}\right)_{2} \mathrm{Gm}\right)_{3}\left(\mathrm{~B} n-\mathrm{C}_{4} \mathrm{H}_{9}\right)_{2}$, were prepared as described elsewhere. ${ }^{[6,7]}$ Carbon paper (CP) Sigracet GDL 39 BC (SGL Group) was used in adsorption experiments.

\section{Physisorption experiments}

The chemical drawings of the mono-, di- and hexaphenanthrene-containing iron(II) cage complexes are shown in Scheme 1. The adsorption isotherms of these three iron complexes and of the Methylene Blue dye (a model compound used for comparison) were determined from the UV-Vis spectrophotometry experiments, using their $0.01-0.5 \mathrm{mM}$ solutions in acetonitrile dichloromethane 2:1 mixture. For each compound, the adsorption

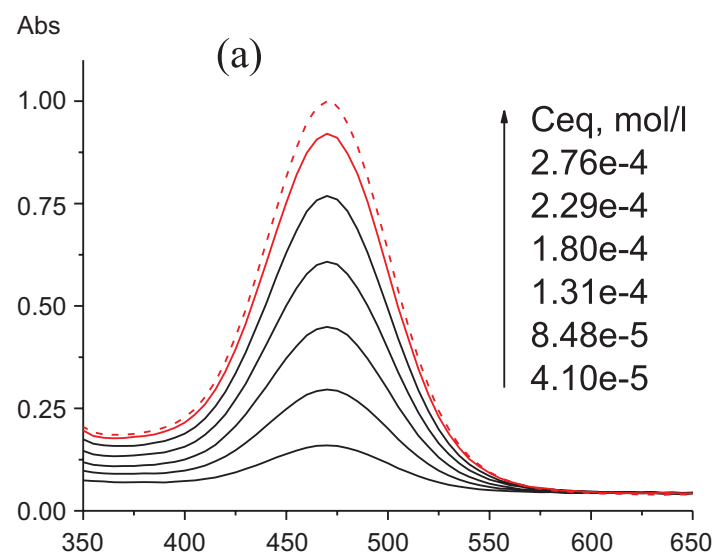

(c)

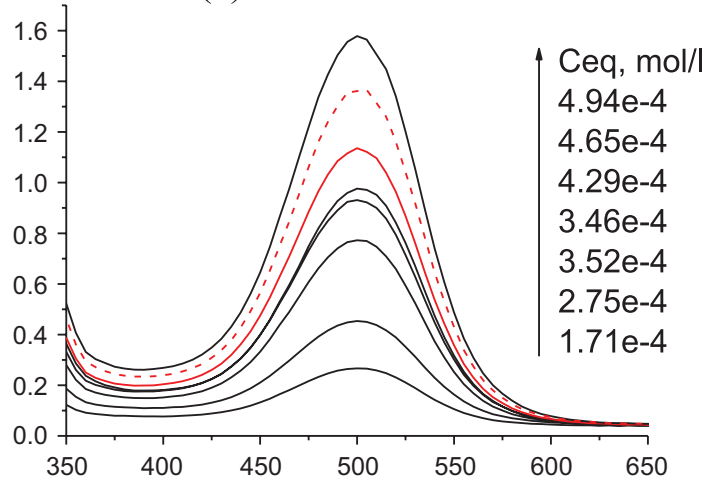

experiment was performed as follows: $2 \mathrm{mg}$ of $\mathrm{CP}$ was added to a vial containing $3 \mathrm{~mL}$ of the given compound in solution. The solution was periodically jolted for $4 \mathrm{~h}$ to favor homogeneity. Then, the solution/suspension thus obtained was centrifugated using a EBA 20 (Hettich) ultracentrifuge, operating at a rotational speed of $5000 \mathrm{rpm}$ for $2 \mathrm{~min}$. Solution aliquots were sampled using a syringe and UV-Vis spectra of a given compound in solution were recorded in the range $230-800 \mathrm{~nm}$ using a Varian Cary 50 spectrophotometer in a quartz cell with $0.1 \mathrm{~cm}$ optical pathway. The initial, intermediate and final concentrations of each compound under study were obtained using the classical equation: $A=\varepsilon \cdot \cdot c$, where $A$ is the optical density, $\varepsilon$ is the molar extinction coefficient, and $l$ is the optical path.

\section{Results and Discussion}

The UV-Vis spectra of four different compounds (three iron clathrochelates under study and the Methylene Blue dye) in solution before, during and at the end of the sorption experiments on CP are shown in Figure 1. The dashed red lines show the initial spectra of these compounds, before their adsorption on CP: (a) $3.00 \cdot 10^{-4}$; (b) $3.50 \cdot 10^{-4}$; (c) $5.58 \cdot 10^{-4}$ and (d) $1.25 \cdot 10^{-4} \mathrm{~mol} \cdot \mathrm{L}^{-1}$, respectively. The solid red lines show their spectra measured at the beginning of the sorption experiments, after addition of CP: (a) $2.76 \cdot 10^{-4}$; (b) $3.13 \cdot 10^{-4}$; (c) $4.65 \cdot 10^{-4}$ and (d) $1.00 \cdot 10^{-4} \mathrm{~mol} \cdot \mathrm{L}^{-1}$, respectively. The solid dark lines show the spectra during the sorption experiment.

(b)
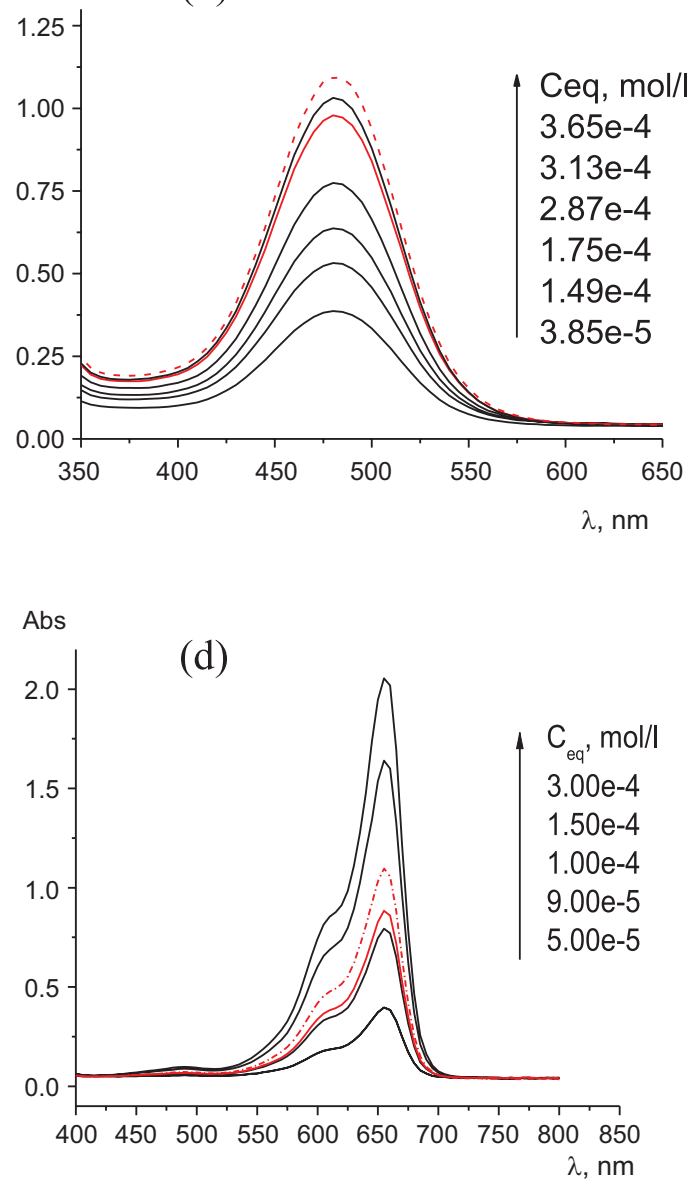

Figure 1. UV-Vis spectra of (a) FeBd $\left(\left(\mathrm{Phen}\left(\mathrm{CH}_{2}\right)_{3} \mathrm{~S}\right) \mathrm{GmH}\right)(\mathrm{BF})_{2}$, (b) $\mathrm{FeBd}_{2}\left(\left(\mathrm{Phen}\left(\mathrm{CH}_{2}\right)_{3} \mathrm{~S}\right)_{2} \mathrm{Gm}\right)(\mathrm{BF})_{2},(\mathrm{c}) \mathrm{Fe}\left(\left(\mathrm{Phen}\left(\mathrm{CH}_{2}\right)_{3} \mathrm{~S}\right)_{2} \mathrm{Gm}\right)_{3}(\mathrm{~B} n$ $\left.\mathrm{C}_{4} \mathrm{H}_{9}\right)_{2}$ and (d) Methylene Blue dye in their dichloromethane - acetonitrile 1:2 solutions during the sorption experiments on CP. 
The adsorption process can be quantitatively characterized by determining the so-called "specific adsorption":[9] this is the amount of an adsorbate (here either a clathrochelate complex or a dye of interest), which can be adsorbed per a unit of weight of a given substrate (here, carbon paper as an adsorbent). The specific adsorption value $G$ can be calculated using Eq. (1):

$$
G=\frac{\left(C_{0}-C_{e q}\right) \cdot V}{m},
$$

where $C_{0}$ is the initial concentration of an adsorbing compound (adsorbate) in solution, $C_{e q}$ is the resulting concentration of adsorbate at equilibrium after adsorption, $V$ is the volume of solution used, and $m$ is the weight of a substrate (adsorbent).

The UV-Vis spectra shown in Figure 1 were used to obtain the adsorption isotherms and to calculate the corresponding specific adsorption coefficient values using Eq. (1). These results are plotted in Figure 2a for Methylene Blue and in Figure 3a for the iron(II) clathrochelates under study. Linear relationships are obtained by plotting $1 / G$ versus

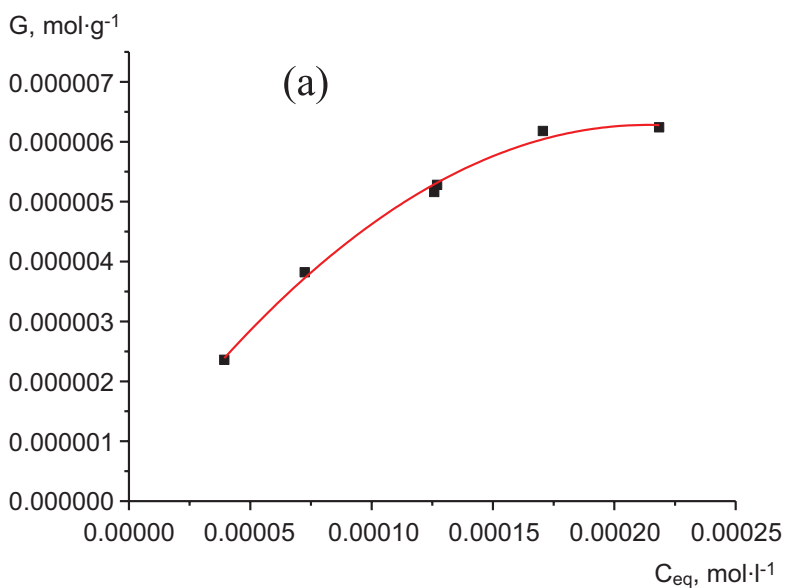

$1 / C_{e q}$ (see Figure $2 \mathrm{~b}$ for Methylene Blue and Figure $3 \mathrm{~b}$ for the clathrochelates under study). The linear regressions of these plots are in good agreement with Eq. (2), which is a general form of the Langmuir adsorption isotherm:

$$
G=G_{\infty} \frac{K C_{e q}}{K C_{e q}+1},
$$

where $G$ and $G_{\infty}$ are the specific and the limiting specific adsorptions, respectively, and $K$ is the adsorption equilibrium constant describing a reversible process:

complex in solution + carbon site $\leftrightarrow$ adsorbed complex $K=[\text { complex }]_{\text {ads }} /[\text { complex }]_{\text {des }}$

Physical meaning of this constant is associated with both the adsorption and desorption processes and it characterizes an energy of the adsorbent - adsorbate interactions.

Finally, the Gibbs free energy changes associated to these adsorption processes were calculated at $\mathrm{T}=298 \mathrm{~K}$ using the classical Eq. (3) that links the Gibbs free energy change of physisorption to the sorption equilibrium constant $K$ :

$$
\Delta G=-R T \ln k
$$

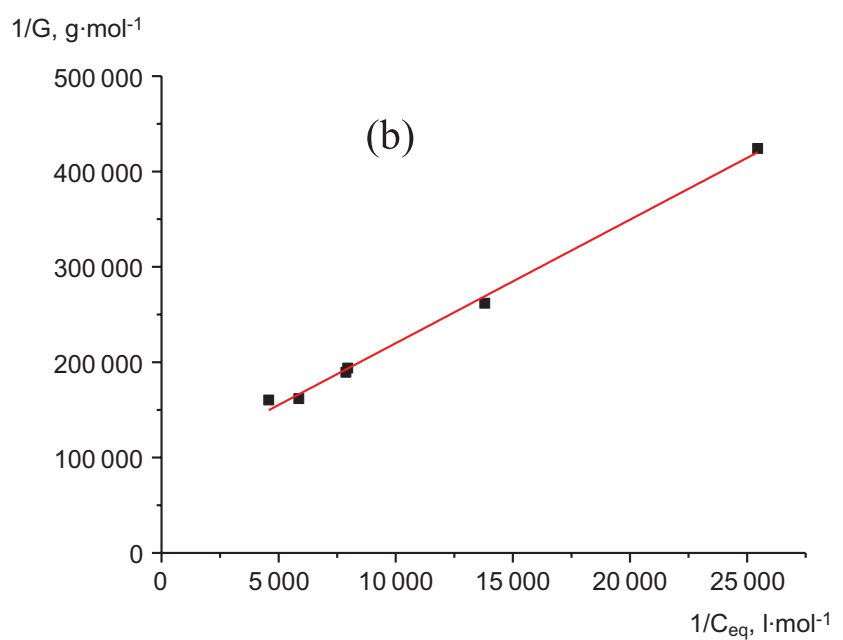

Figure 2. Methylene Blue dye: (a) the Langmuir adsorption isotherm, and (b) the plot used to determine the adsorption constant $K$.
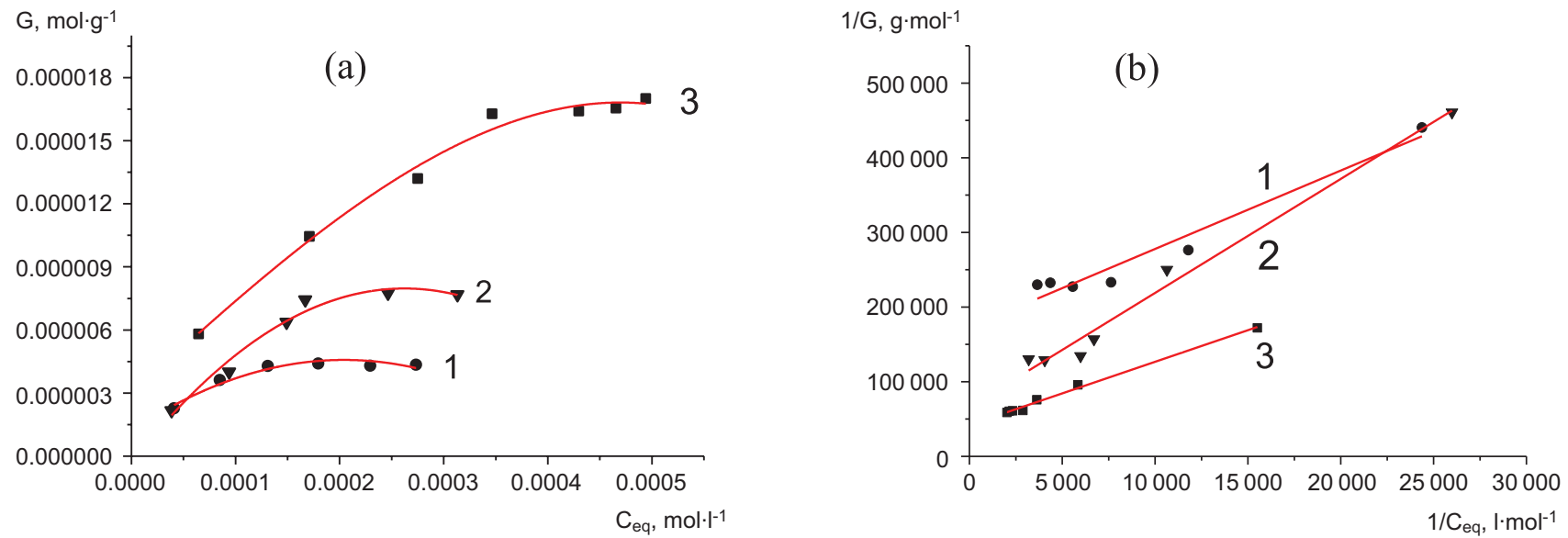

Figure 3. (a) Langmuir adsorption isotherms of the iron(II) clathrochelates under study, and (b) plots used for the determination of their adsorption constants $K$ on CP: (1) FeBd ${ }_{2}\left(\left(\mathrm{Phen}\left(\mathrm{CH}_{2}\right)_{3} \mathrm{~S}\right) \mathrm{GmH}\right)(\mathrm{BF})_{2} ;(2) \mathrm{FeBd}_{2}\left(\left(\mathrm{Phen}\left(\mathrm{CH}_{2}\right)_{3} \mathrm{~S}\right)_{2} \mathrm{Gm}\right)(\mathrm{BF})_{2}$;

(3) $\mathrm{Fe}\left(\left(\mathrm{Phen}\left(\mathrm{CH}_{2}\right)_{3} \mathrm{~S}\right)_{2} \mathrm{Gm}\right)_{3}\left(\mathrm{~B} n-\mathrm{C}_{4} \mathrm{H}_{9}\right)_{2}$. 
Table 1. Physisorption parameters of the Methylene Blue dye and the iron(II) clathrochelates under study onto CP.

\begin{tabular}{ccccc}
\hline Parameter & $\begin{array}{c}\text { Methylene } \\
\text { Blue }\end{array}$ & $\mathrm{FeBd}_{2}\left(\left(\mathrm{Phen}\left(\mathrm{CH}_{2}\right)_{3} \mathrm{~S}\right) \mathrm{GmH}\right)(\mathrm{BF})_{2}$ & $\mathrm{FeBd}_{2}\left(\left(\mathrm{Phen}\left(\mathrm{CH}_{2}\right)_{3} \mathrm{~S}\right)_{2} \mathrm{Gm}\right)(\mathrm{BF})_{2}$ & $\mathrm{Fe}\left(\left(\mathrm{Phen}\left(\mathrm{CH}_{2}\right)_{3} \mathrm{~S}\right)_{2} \mathrm{Gm}\right)_{3}\left(\mathrm{~B} n-\mathrm{C}_{4} \mathrm{H}_{9}\right)_{2}$ \\
\hline$G_{\infty}\left(\mathrm{mol} \cdot \mathrm{g}^{-1}\right)$ & $1.11 \cdot 10^{-5}$ & $5.80 \cdot 10^{-6}$ & $1.51 \cdot 10^{-5}$ & $2.38 \cdot 10^{-5}$ \\
$K$ & $6.95 \cdot 10^{3}$ & $1.64 \cdot 10^{4}$ & $4.34 \cdot 10^{3}$ & $4.96 \cdot 10^{3}$ \\
$\Delta G\left(\mathrm{~kJ} \cdot \mathrm{mol}^{-1}\right)$ & -21.92 & -24.05 & -20.75 & -21.08 \\
\hline
\end{tabular}

$G_{\infty}, K$ and $\Delta G$ values of the Methylene Blue dye and three iron(II) clathrochelates under study were determined using Eqs. (2) and (3); the results obtained are collected in Table 1.

As can be seen from the data of Table 1, the large $K$ values indicate that the sorption process is displaced towards the adsorbed species. $G_{\infty}$ and $K$ values for Methylene Blue, the molecule of which contains one polyaromatic fragment, are found between those for the mono- and diphenanthrene cage complexes. Both the $G_{\infty}$ and $K$ values increase when passing from mono-, to di- and hexa-functionalized iron(II) clathrochelates (Scheme 1), thus indicating an increase in their adsorption on CP. There is hence a simple correlation between the number of polyaromatic groups per a clathrochelate molecule (from one to six) and the strength of adsorption. A similar trend was reported earlier ${ }^{[7]}$ while using RGO used as carbonaceous substrate.

\section{Conclusions}

The physisorption of three designed iron(II) clathrochelates, viz. $\left(\mathrm{FeBd}_{2}\left(\left(\mathrm{Phen}\left(\mathrm{CH}_{2}\right)_{3} \mathrm{~S}\right) \mathrm{GmH}\right)(\mathrm{BF})_{2}\right.$, $\mathrm{FeBd}_{2}\left(\left(\mathrm{Phen}\left(\mathrm{CH}_{2}\right)_{3} \mathrm{~S}\right)_{2} \mathrm{Gm}\right)(\mathrm{BF})_{2}$, and $\left(\left(\mathrm{Phen}\left(\mathrm{CH}_{2}\right)_{3} \mathrm{~S}\right)_{2} \mathrm{Gm}\right)_{3}$ $\left.\left(\mathrm{B} n-\mathrm{C}_{4} \mathrm{H}_{9}\right)_{2}\right)$, on a carbon paper, which is commonly used as GDL in fuel cell technology, was studied by UV-Vis spectrophotometry. The equilibrium constant and Gibbs free energy changes associated to their physisorption process were determined at $298 \mathrm{~K}$. It was found that the larger the number of polyaromatic group in the clathrochelate, the stronger the physisorption is. In other words, it can be concluded that despite a larger sterical clashes the cage complexes with several polyaromatric groups are prone to stronger physisorption on carbonaceous substrates. This is a result of interest that will be used to produce monolayer thick coatings of these cheap complexes of an abundant metal onto the carbon fibers of gas-diffusion layers for application at the cathode of PEM water electrolysis cells.
Acknowledgements. The synthesis of cage complexes was supported by Russian Science Foundation (grant 17-13-01468). Y.Z.V., I.G.B., A.S.B. and S.A.G also thank the Russian Foundation for Basic Research (grants 18-0300675, 16-33-60196 and 17-03-00587) and the Ministry of Education and Science of the Russian Federation (government task in the field of scientific activities, project No.16.7113.2017/6.7) for the support of electrochemical studies. A.G.D. also thanks the Ministry of Education and Science of the Russian Federation for the financial support in the framework of the State task "Leading researchers at a permanent position", project 4.6718.2017/6.7 (profile №1422). The financial support of A.S.P. was provided by the NRC "Kurchatov Institute” (№1390).

\section{References}

1. Clathrochelates: Synthesis, Structure and Properties (Voloshin Y.Z., Kostromina N.A., Krämer R., Eds.). Amsterdam: Elsevier, 2002. $419 \mathrm{p}$.

2. Rifkin J. The Hydrogen Economy: the Creation of the Worldwide Energy Web and the Redistribution of Power on Earth. UK: Polity Press, 2003.

3. Pantani O., Nascar S., Guillot R., Millet P., Anxolabéhère-Mallart E., Aukauloo A. Angew. Chem. Int. Ed. 2008, 120, 10096.

4. Dinh Nguyen M-T., Ranjbari A., Catala L., Brisset F., Millet P., Aukauloo A. Coord. Chem. Rev. 2012, 256, 2435.

5. Voloshin Y.Z., Belaya I.G., Krämer R. Cage Metal Complexes: Clathrochelates Revisited. Heidelberg: Springer, 2017.

6. Varzatskii O.A., Oranskiy D.A., Vakarov S.V., Chornenka N.V., Belov A.S., Vologzhanina A.V., Pavlov A.A., Grigoriev S.A., Pushkarev A.S., Millet P., Kalinichenko V.N., Voloshin Y.Z., Dedov A.G. Int. J. Hydrogen Energy 2017, 27894.

7. Voloshin Y.Z., Chornenka N.V., Varzatskii O.A., Belov A.S., Grigoriev S.A., Pushkarev A.S., Millet P., Kalinichenko V.N., Belaya I.G., Bugaenko M.G., Dedov A.G. Electrochim. Acta 2018, 269, 590.

8. Siracusano S., Baglio V., Grigoriev S.A., Merlo L., Fateev V.N., Arico A.S. J. Power Sources 2017, 366, 105.

9. Trasatti S., Parsons R. Pure Appl. Chem. 1986, 58, 437. 